\title{
Intraindividual variation in nuclear DNA content in Durvillaea antarctica (Chamisso) Hariot, Macrocystis pyrifera (Linnaeus) C. Agardh and Lessonia spicata (Suhr) Santelices (Phaeophyceae)
}

\author{
Noemi SALVADOR SOLER \\ Instituto de Ciencias Biomédicas, Facultad de Ciencias de la Salud, \\ \& Centro de Investigación Multidisciplinario de La Araucanía (CIMA) \\ Universidad Autónoma de Chile, Temuco, 4810101 (Chile) \\ noemi.salvador@uautonoma.cl (corresponding author) \\ Jordi RULL LLUCH \\ Amelia GÓMEZ GARRETA \\ Laboratori de Botànica, Facultat de Farmàcia i Ciències de l'Alimentació \\ \& Institut de Recerca de la Biodiversitat (IRBio), \\ Universitat de Barcelona, E-08028, Barcelona (Spain)
}

Submitted on 30 May 2018 | Accepted on 10 October 2018 | Published on 6 March 2019

KEY WORDS C-value,

DNA content, Fucales, Laminariales,
polyploidy.
Salvador Soler N., Rull Lluch J. \& Gómez Garreta A. 2019. - Intraindividual variation in nuclear DNA content in Durvillaea antarctica (Chamisso) Hariot, Macrocystis pyrifera (Linnaeus) C. Agardh and Lessonia spicata (Suhr) Santelices (Phaeophyceae). Cryptogamie, Algologie 40 (2): 5-12. https://doi.org/10.5252/cryptogamie-algologie2019v40a2. http://cryptogamie.com/algologie/40/2

\section{ABSTRACT}

Macrocystis C. Agardh, Durvillaea Bory and Lessonia Bory are three brown seaweeds genera of commercial importance for Chilean fishermen. Macrocystis pyrifera (Linnaeus) C. Agardh (Laminariales, Laminariaceae) is one of the world's most ecologically and economically important seaweed collected in Chile for alginate extraction; and as food for abalone aquaculture, Lessonia spicata (Suhr) Santelices (Laminariales, Lessoniaceae) represents more than $70 \%$ of the total brown seaweeds annual landing in Chile; and Durvillaea antarctica (Chamisso) Hariot (Fucales, Durvillaeaceae) is consumed as food, being considered very healthy because of its iodine content. Despite the economic importance of these species their nuclear DNA content is unknown until this moment. The present research was initiated to determine the nuclear DNA content and the intraindividual ploidy level variation in these seaweeds. The DNA-localizing fluorochrome DAPI (4',6-diamidino-2-phenylindole) and red blood cell (chicken erythrocyte) standard were used to estimate the nuclear DNA contents by image analysis. Durvillaea antarctica presented lower 2C DNA $(1.2 \mathrm{pg})$ content and narrower range of DNA contents (1C-2C) than the Laminariales, which showed higher 2C DNA contents (1.4-1.5 pg) and a wider range of ploidy level, achieving up to $4 \mathrm{C}$ in L. spicata and up to $8 \mathrm{C}$ in M. pyrifera. This higher ploidy levels observed would be related with the more complex cortical organization in the Laminariales than D. antarctica. 1C nuclei were only found in mature antheridia (D. antarctica) and sporangia (M. pyrifera and L. spicata). The $2 \mathrm{C}$ values observed for the taxa assessed were in the range of other previously published Fucales and Laminariales. 


\begin{abstract}
RÉSUMÉ
Variation intra-individuelle du contenu en ADN nucléaire de Durvillaea antarctica, Macrocystis pyrifera et Lessonia spicata (Phaeophyceae).

Macrocystis C. Agardh, Durvillaea Bory et Lessonia Bory sont trois genres d'algues brunes d'importance commerciale pour les pêcheurs chiliens. Macrocystis pyrifera (Linnaeus) C. Agardh (Laminariales, Laminariaceae) est, parmi les algues récoltées au Chili, l'une des plus importantes au monde sur les plans écologique et économique; comme aliment pour l'aquaculture de l'ormeau, Lessonia spicata (Suhr) Santelices (Laminariales, Lessoniaceae) représente plus de $70 \%$ du total annuel des algues brunes débarquées au Chili ; et Durvillaea antarctica (Chamisso) Hariot (Fucales, Durvillaeaceae) est consommée comme aliment, car elle est considérée comme très saine en raison de sa teneur en iode. Malgré l'importance économique de ces espèces, leur contenu en ADN nucléaire est resté inconnu jusqu’à présent. L'objectif de la présente étude est de déterminer le contenu en $\mathrm{ADN}$ nucléaire et la variation du niveau de ploïdie intra-individuelle chez ces algues. Le fluorochrome DAPI (4',6-diamidino-2-phenylindole) permettant la localisation de l'ADN a été utilisé, suite à un étalonnage avec des érythrocytes de poulet, pour estimer par analyse d'image leur contenu en ADN nucléaire. Durvillaea antarctica présentait un contenu inférieur en $\mathrm{ADN} 2 \mathrm{C}(1,2 \mathrm{pg})$ et une gamme plus étroite de contenu en $\mathrm{ADN}$ (1C-2C) que les Laminariales, qui présentaient des teneurs en $\mathrm{ADN} 2 \mathrm{C}$ plus élevées $(1,4$ à $1,5 \mathrm{pg}$ ) et une gamme plus étendue de taux de plö̈die, atteignant jusqu’à $4 \mathrm{C}$ chez L. spicata et jusqu'à $8 \mathrm{C}$ chez $M$. pyrifera. Les niveaux de ploïdie plus élevés observés seraient liés à l'organisation corticale plus complexe des Laminariales relativement à celle de $D$. antarctica. Les noyaux $1 \mathrm{C}$ n'ont été trouvés que dans des anthéridies matures $(D$. antarctica) et des sporanges ( $M$. pyrifera et $L$. spicata). Les valeurs de $2 \mathrm{C}$ observées pour les taxons évalués se situaient dans la plage des autres Fucales

et Laminariales publiées antérieurement.

\author{
C-value, \\ contenu en $\mathrm{ADN}$ \\ Fucales, \\ Laminariales, \\ polyploïdie.
}

MOTS CLÉS
\end{abstract}

\section{INTRODUCTION}

The kelp fishery in Chile lands up to 300000 dry tons annually and the industry has an economic value exceeding $c$. US $\$ 60$ million (Vásquez 2008; Vásquez et al. 2012). According to Vásquez et al. (2012) the three brown seaweeds genera of commercial importance for Chilean fishery are Macrocystis C. Agardh (Laminariales, Laminariaceae), Durvillaea Bory (Fucales, Durvillaeaceae) and Lessonia Bory (Laminariales, Lessoniaceae). Macrocystis is one of the world's most ecologically and economically important taxa (Demes et al. 2009). Several studies about marine ecological interrelationships have identified Macrocystis pyrifera (Linnaeus) C. Agardh as an important refuge environment from herbivory, for nurseries of invertebrates and fish (Macchiavello et al. 2010). In Chile, it has been exploited along the Northern and central zones being used as a foodstuff in the cultivation of abalone (Haliotis spp.) and exported, ground up, for the extraction of alginic acid (Vásquez 2008). Lessonia spicata (Suhr) Santelices represents more than $70 \%$ of the total brown seaweed annual landing in Chile (Vásquez et al. 2012) and Durvillaea antarctica (Chamisso) Hariot is culturally recognized as a food named cochayuyo that also has high nutritional value due to its essential nutrients content (Hoffmann \& Santelices 1997). Although, there is a national and international demand for brown seaweeds, it is not satisfied by algal species like Laminaria J.V. Lamouroux, Durvillaea, Ecklonia Hornemann, Sargassum C. Agardh and Lessonia (Alveal et al. 1990).

The genome size or $\mathrm{C}$-value is the amount of nuclear DNA in a cell which represents multiples of the minimum amounts of DNA corresponding to the non-replicated haploid chromosome complement (Greilhuber et al. 2005). Increasing interest in such data is evidenced by the number of newly estimated C-values published in recent years (Bennett \& Leitch 2011) due to the nuclear DNA content is used in a wide range of biological fields as ecological or environmental indicators (Kubešová et al. 2010) as well as predictors of phenotypic characters at cell, tissue or organism level (Beaulieu et al. 2008; Hodgson et al. 2010). Moreover, these data have been related to patterns of both invasiveness (Lavergne et al. 2010) and evolution (Leitch \& Leitch 2013), inclusive in the macroalgae (Kapraun 2005; Phillips et al. 2011). According to Browdy et al. (2012), genomic data are important to ensure a sustainable aquaculture of macroalgae.

The first compilation of genome size estimates in algae was addressed by Kapraun (2005) with 245 species of red, brown and green macroalgae. Later, these data were incorporated into the database of plant genome size hosted by the Royal Botanic Gardens Kew web page (http://data.kew.org/cvalues/). To date, the latest contributions of new estimates of nuclear DNA contents for the brown algae were provided by Gómez Garreta et al. (2010), Phillips et al. (2011), Ribera Siguan et al. (2011) and Martin Martin et al. 2016 who included 19, 98, 17 and 5 additional taxa, respectively. Recently, Sjøtun et al. (2017) identified large variation in genome size within populations of the genus Fucus Linnaeus. All these previous studies highlighted the absence of published DNA content data of the ecologically and economically important Fucales and Laminariales. In addition, no C-value data for any southern hemisphere Fucales are available (Phillips et al. 2011).

The nuclear DNA variation within individuals has been studied in a variety of plant groups (Biradar \& Rayburn 1993). In the algae it was initiated by Goff \& Coleman (1984) who not only mapped the DNA content within individuals but 

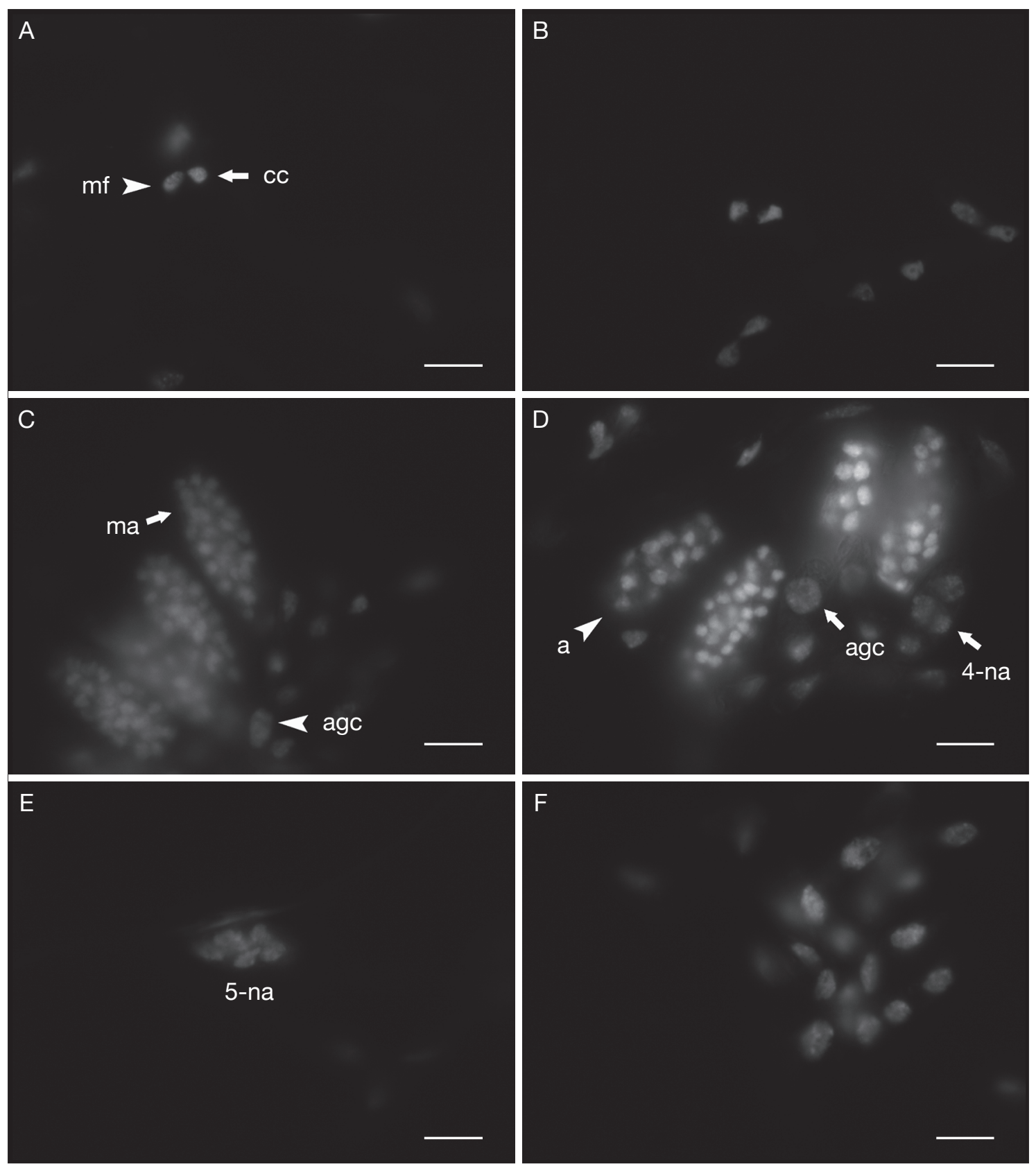

FIG. 1. - Cells of Durvillaea antarctica (Chamisso) Hariot stained with DAPI: A, mitotic figure (mf) of dividing cortical cells (cc); B, uninucleate cortical cells; C, D, mature antheridia (ma), antheridia germinative cells (agc), antheridium (a) and four-nucleate antheridium (4-na); E, five-nucleate antheridium (5-na); F, antheridia germinative cells. Scale bars: A-D, $5 \mu \mathrm{m}$.

throughout the life history of a single species. Afterwards, the same authors conclude their extensive research with the description of both major nuclear patterns associated with DNA intraindividual variation in the red algae and phenomena associated with the DNA dynamics such as polyploidy and polygenomy (Goff \& Coleman 1990).

Several studies have reported polyploidy in the Laminariales (Lewis 1996; Phillips et al. 2011) and Fucales (Coyer et al. 2006; Gómez Garreta et al. 2010; Sjøtun et al. 2017). According to Kapraun (2005) its larger genome sizes $(2 \mathrm{C} \geq 2.0 \mathrm{pg})$ almost certainly are related with this phenomenon. Müller et al. (2016) reported one ploidy variant in their gametophyte cultures and Coyer et al. (2006) identified polyploid Fucus species adapted to salt marshes.

On the other hand, the measurement of the nuclear DNA level provides also key information for a better understanding of the life history in the macroalgae. In this sense Müller et al. (2016) reported sex specific polyteny in Macrocystis gametophyte cultures, observing in female gametophytes approximately double the DNA content than in male gametophytes.

The estimation of the nuclear DNA content provides useful information not only to understand the complex life histories but morphologies of the red macroalgae (Goff \& Coleman 1990; Salvador et al. 2009). Taking into account the pres- 

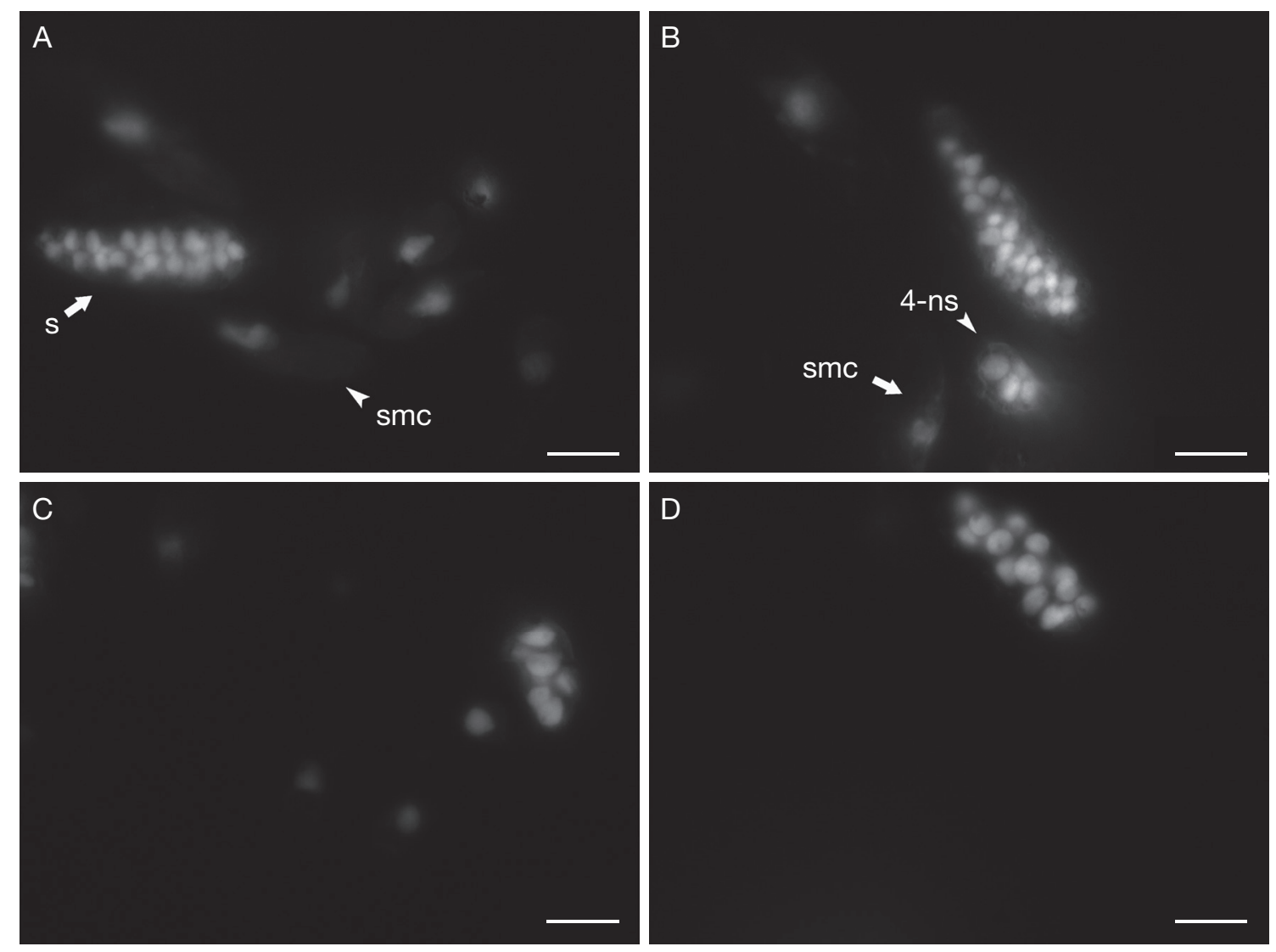

FIG. 2. - Developmental stages of sporangia in Lessonia spicata (Suhr) Santelices stained with DAPI: A, sporangia (s) and sporangial mother cells (smc); B, four-nucleate sporangium (4-ns) and sporangial mother cells (smc); C, D, different developmental stages of the sporangia. Scale bars A-D, $5 \mu \mathrm{m}$.

ence of DNA intraindividual variation in the macroalgae, the DNA quantification from various tissues is relevant for the interpretation of DNA content measurements in macroalgae in this type of studies. In this sense, endopolyploid nuclei (8C) were reported in vegetative tissue of Saccharina latissima (Linnaeus) C.E. Lane, C. Mayes, Druehl \& G.W. Saunders (as Laminaria saccharina (Linnaeus) Lamouroux) and Alaria esculenta (Linnaeus) Greville (Garbary \& Clarke, 2002). Later, Kapraun (2005) observed large nuclei in older medullary cells of S. latissima (as L. saccharina) which were not possible to quantify. Taking into account the wide range of cell sizes in individual thalli of many brown algae, it has not been studied in the context of nuclear endopolyploidy.

The present investigation was initiated to determine the nuclear DNA content and variation of the level of intraindividual ploidy of $M$. pyrifera, L. spicata and D. antarctica, three marine species of the southern hemisphere. Despite the economic importance of these species, their nuclear DNA content had not been estimated so far.

\section{MATERIAL AND METHODS}

\section{ALGAL MATERIAL}

Reproductive specimens of Durvillaea antarctica, Lessonia spicata and Macrocystis pyrifera were collected from Cocholgüe
(Biobío Region), Chile (36³5'38.41”S, 7258’43.85”W) in June 2014. Samples were collected during low tide at rocky platforms. Fertile fragments were cut off from each plant and preserved in Carnoy's fixative (3:1 of 95\% ethanol-glacial acetic acid) and stored in $70 \%$ ethanol at $4{ }^{\circ} \mathrm{C}$ (Kapraun 2005). Voucher specimens were deposited at the BCN-Phyc. Herbarium (Documentation Center of Plant Biodiversity, University of Barcelona, Spain).

\section{MiCROFLUOROMETRIC ANALYSIS}

Samples were rehydrated in water and softened in 5\% w/v EDTA for $72 \mathrm{~h}$. Algal material was squashed and transferred to coverslips treated with subbing solution and then air dried and stained with $0.5 \mu \mathrm{g} \mathrm{mL}$ of DAPI (4'-6-diamidino-2-phenylindole; Sigma Chemical Co., St. Louis, Missouri, USA). Nuclear DNA content estimates based on image analysis of DAPI-stained specimens followed a procedure modified from Kapraun \& Dunwoody (2002) and Choi et al. (1994) using a Cooled CCD Miramax RTE 782-Y high performance digital camera placed on a Leica DMRB fluorescence microscope and consequently analyzed using MetaMorph software (Molecular Devices, Toronto, Canada). The total intensity (in relative fluorescence units, rfu) was estimated from image analysis. According to Varela-Álvarez et al. (2012), microspectrophotometry followed by image analyses allows the user to observe and differentiate every single data unit 

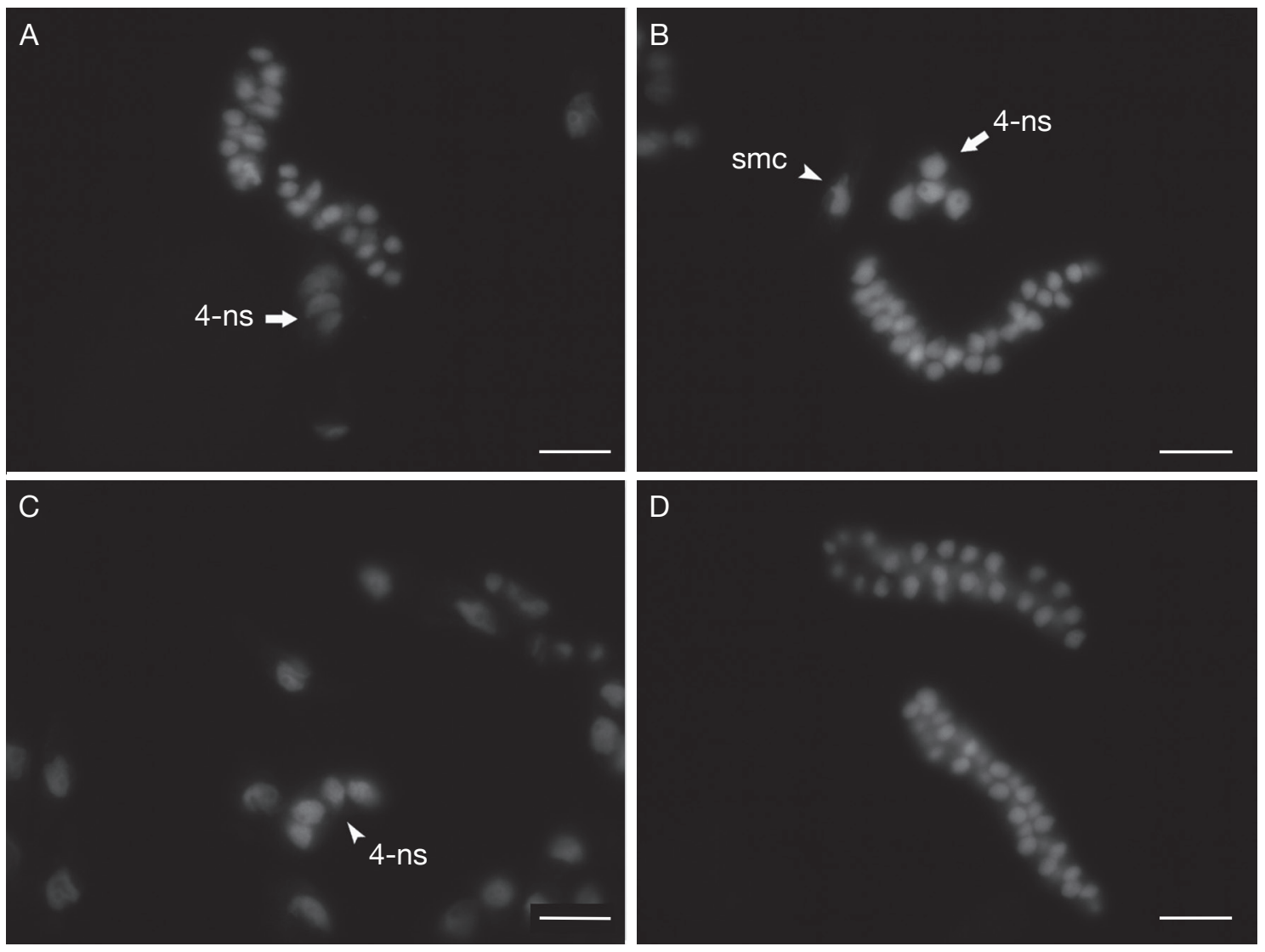

FIG. 3. - Developmental stages of sporangia in Macrocystis pyrifera (Linnaeus) C. Agardh stained with DAPI: A-C, four-nucleate sporangium (4-ns) and sporangial mother cells (smc); $\mathbf{D}$, mature sporangia. Scale bars: A-D, $5 \mu \mathrm{m}$.

obtained. Nuclei from diverse regions of the thallus (cortex, medulla) can be identified and checked by optical microscopy before the fluorescence microscope, thus this technique is more rigorous despite having the drawback of being slower than flow cytometry.

DAPI binds by a non-intercalative mechanism to adenine and thymine rich regions of DNA that contain at least four A-T base pairs (Portugal \& Waring 1988). Chicken erythrocytes (RBC) with a DNA content of 2.4 picograms (pg) were used as a standard to quantify nuclear DNA contents (Clowes et al. 1983). RBC can be used directly as a standard for determining amounts of DNA only when the A-T contents of both standard and experimental DNA are equivalent (Coleman et al. 1981). A nuclear DNA base composition of $42-43 \mathrm{~mol} \% \mathrm{G}+\mathrm{C}$ was determined in the chicken by Marmur \& Doty (1962) and of $53 \%$ in the Ectocarpus siliculosus by Cock et al. (2010). These published data indicate similar mean mol \% values and linearity is presumed between DAPI-DNA binding in both RBC and algal samples (Le Gall et al. 1993).

Nuclear DNA contents were estimated by comparing the total intensity of fluorescence ( $\mathrm{rfu}$ ) values of the RBC standard and algal samples (Kapraun \& Nguyen 1994). Nuclear DNA content reflects the position of a cell within a cell cycle, and the $\mathrm{C}$-values inferred from the nuclear relative fluorescent units (rfu) measurements represented G1, S and G2 phases of the cell population examined. Measurements of reproductive cells are considered the best way to determine the numerical relationship between rfu and C-values (Goff \& Coleman 1990). In addition, mitotic figures in dividing somatic cells were measured to confirm the $1 \mathrm{C}$ level.

Nuclear DNA content data obtained herein will be incorporated into the database of plant genome sizes (Kapraun 2005, Gregory et al. 2007) compiled and hosted by the Royal Botanic Gardens (RBG) Kew web page.

\section{RESULTS AND DISCUSSION}

A total of 777 nuclei (algae and standard together) were localized and measured. Durvillaea antarctica showed the lowest nuclear DNA content $(2 \mathrm{C}=1.2 \mathrm{pg})$ as well as the narrowest range of ploidy level (1C-2C) in comparison with the Laminariales analyzed taxa (Table 1). This data represents the first C-value for a southern hemisphere representative of Fucales. Lessonia spicata and Macrocystis pyrifera exhibited the highest nuclear DNA contents $(2 \mathrm{C}=1.4-1.5 \mathrm{pg})$ and ploidy levels, achieving up to $4 \mathrm{C}$ and $8 \mathrm{C}$ in L. spicata and $M$. pyrifera, respectively (Table 1 ). The data reported here are in agreement with those observed by Phillips et al. (2011), being the $2 \mathrm{C}$ values observed inside the range of DNA content values of the Fucales and Laminariales published by these authors. 
TABLE 1. - Nuclear DNA content with corresponding $C$ levels in different cell types of the species examined. Abbreviations: A, antheridia; P, paraphyses; C, cortical cells; S, sporangia; cells; pg, picograms; Me, meristoderm; n, number of nuclei analyzed.

\begin{tabular}{|c|c|c|c|c|c|}
\hline & \multicolumn{2}{|c|}{ DNA content (pg) } & \multirow[b]{2}{*}{ Ploidy level } & \multirow[b]{2}{*}{ Cell types } & \multirow[b]{2}{*}{$\mathbf{n}$} \\
\hline & mean & sd & & & \\
\hline Durvillaea & 0.6 & 0.1 & $1 C$ & $A$ & 28 \\
\hline antarctica & 1.2 & 0.2 & $2 \mathrm{C}$ & $A$ & 25 \\
\hline (Chamisso) & 1.2 & 0.2 & $2 \mathrm{C}$ & $P$ & 67 \\
\hline Hariot & 1.2 & 0.2 & $2 \mathrm{C}$ & C & 118 \\
\hline Lessonia & 0.8 & 0.1 & $1 \mathrm{C}$ & $S$ & 23 \\
\hline spicata & 0.9 & 0.2 & $1 \mathrm{C}$ & $\mathrm{Me}$ & 3 \\
\hline (Suhr) & 1.5 & 0.2 & $2 \mathrm{C}$ & $\mathrm{Me}$ & 3 \\
\hline Santelices & - & - & $1 \mathrm{C}-4 \mathrm{C}$ & $\mathrm{C}$ & 26 \\
\hline Macrocystis & 0.7 & 0.1 & $1 \mathrm{C}$ & $S$ & 112 \\
\hline pyrifera & 1.4 & 0.2 & $2 \mathrm{C}$ & C & 70 \\
\hline (Linnaeus) & - & - & $2 C-8 C$ & C & 178 \\
\hline
\end{tabular}

Vegetative and reproductive cells were analyzed separately. All the cells observed in the studied taxa were uninucleate. A similar DNA content $(2 \mathrm{C}=1.2)$ among different cell types of $D$. antarctica was observed (Table 1). Concerning cortical cells, this fact could be related with the uniform cell size of this tissue that Collantes et al. (2002) described as several rows of uniform cells arranged neatly. In contrast, a major variation in ploidy levels in the cortex of the kelp fronds was observed (Table 1), due to its major range in cell size in comparison with $D$. antarctica. Similarly, Garbary \& Clarke (2002) suggested that all multicellular plant groups having a major range in cell size show higher variation in nuclear DNA amount. Even more, according to several authors the nuclear DNA levels correlate positively with cell size (Kapraun 2005; Beaulieu et al. 2008; Hodgson et al. 2010; Katagiri et al. 2016), facilitating the association of $C$ levels with different cell types. Nevertheless, in L. spicata and M. pyrifera, the wide ranges of ploidy levels observed in their cortical cells were not apparently related with the cell size, making it difficult the calculation of the mean $\mathrm{C}$ values in this cell type (Table 1 ). Furthermore, some cortical cells of L. spicata exhibited the same low values (1C-2C) observed in the meristoderm cells (Table 1). Garbary \& Clarke (2002) obtained similar results in Saccharina latissima (as Laminaria saccharina) explaining this fact by the presence of some cortical cells that change their vacuolar volume while preserving a constant cytoplasmic volume. Previous studies (Davies et al. 1973; Chung et al. 1987) confirm the low vacuolar volume in meristoderm cells of Laminaria in comparison with their higher volume in cortical cells, which are highly vacuolated too. Recently, the observations of Katagiri et al. (2016) suggested that the cell type is a factor to consider in the relationship between nuclear DNA content and cell size.

Regarding the reproductive cells, they were clearly identified in different developmental stages (Figs 1-3). 1C values were observed in mature antheridia and sporangia of studied species (Table 1; Figs 1-3), but neither in the four-nucleate antheridia of $D$. antarctica (Figs. 1D-F) nor in this stage of the sporangia of the Laminariales (Figs 2B; 3A-C) as would be expected after meiosis. Similarly, the observations of Collantes et al. (2002) on the four-nucleate antheridia showed bigger nuclei indicating higher DNA contents than a $1 \mathrm{C}$ value, thus unexpected values for post-meiotic nuclei. Even more, in the following divisions of Laminariales sporangia and antheridia of $D$. antarctica the nuclear DNA content decrease considerably. These observations are consistent with those observed by Garbary \& Clarke (2002) in Alaria esculenta, who detailed the nuclear ploidy changes during sporogenesis. Following meiosis they observed $8 \mathrm{C}$ nuclei instead the $1 \mathrm{C}$ expected in the four-nucleate stage and reductions in DNA content in the following mitotic divisions until the nuclei reach the $2 \mathrm{C}$ level instead the DNA synthesis before the mitosis to maintain the $1 \mathrm{C}$ level expected. Several authors confirmed the presence of meiosis in the first division of the sporangia in other brown algae (Robinson \& Cole 1971; Loiseaux 1973; Katsaros \& Galatis 1986; Motomura 1993) and others identified the haploid chromosome complement at the four-nucleate sporangia of some Alaria and Laminaria species (Magne 1952; Robinson \& Cole 1971). For this reason Garbary \& Clarke (2002) suggested that no $1 \mathrm{C}$ nuclei are observed in this stage of the sporogenesis by its extremely rapid endoreduplication. By means of this process, the cell cycle skips the mitotic phase increasing the ploidy level and resulting in polyploid cells (Katagiri et al. 2016). According to the detailed study about gametogenesis, fertility and embryogenesis by Collantes et al. (2002) the germinative cells of antheridia are originated by cellular differentiation of the cortical cells. In our study the germinative cells of $D$. antarctica (Fig. 1D-F) showed higher nuclei than those observed in their cortical cells with $2 \mathrm{C}$ values (Fig. 1A-B) suggesting that this cell differentiation could imply endoreduplication. This process is believed to contribute to the activation of metabolism for cell growth and differentiation (Katagiri et al. 2016).

Examples of endopolyploidy in reproductive cells have been observed before in both Phaeophyceae and Rhodophyta. Bothwell et al. (2010) observed partheno-sporophytes derived from haploid filaments of the brown alga Ectocarpus which produces meiospores via endoreduplication. Oppliger et al. (2014) observed unreduced ( $2 \mathrm{~N})$ spores which formed phenotipically normal gametophytes formed in part by automixis. In the Rhodophyta, Salvador et al. (2009) observed an endoreduplication process in the carposporangia production achieving values up to $6 \mathrm{C}$ in Bonnemaisonia clavata $\mathrm{G}$. Hamel and 8C in Bonnemaisonia asparagoides (Woodward) C. Agardh. A similar pattern of endoreduplication was observed in the sporogenesis of the red alga Gelidium chilense (Montagne) Santelices \& Montalva (Salvador et al. 2016), in this case the sporangia achieved values from $4 \mathrm{C}$ to $16 \mathrm{C}$.

\section{CONCLUSIONS}

The main conclusions of this study are: 1) Both nuclear DNA contents and ploidy levels in Laminariales examined here were higher than in $D$. antarctica; 2) $1 \mathrm{C}$ values were observed in 
mature antheridia and sporangia of studied species but no in their four-nucleate stage as it would be expected after a meiosis; 3) Meiosis was not observed in the sporogenesis of L. spicata and $M$. pyrifera or the male gametogenesis of D. antarctica; 4) Endoreduplication was observed during the development of the reproductive cells from its differentiation from meristoderm or cortical cells; and 5) Higher ploidy values (4C, 8C) were related to variation in cell sizes in the cortical organization of the Laminariales.

\section{Acknowledgements}

This work was supported by "DIP 40-2015" project of Universidad Autónoma de Chile (Dirección de Investigación y Postgrado). We are grateful to Erasmo Macaya for providing us algal material from Chile. At last, the authors thank the two anonymous reviewers who read a previous version of the manuscript.

\section{REFERENCES}

Alveal K., Candia A., Collantes G., Edding M., Fonk E., Melo R., Poblete A., Rivera P., Romo H., Werlinger C. \& WestERMEIER R. 1990. - Situación de desarrollo y explotación de los recursos algales de Chile. Red Algas Marinas. CIID, Canadá, 79 p.

Beaulieu J. M., Leitch I. J., Patel S., Pendharkar A. \& Knight C. A. 2008. - Genome size is a strong predictor of cell size and stomatal density in angiosperms. New Phytologist 179: 975-986. https://doi.org/10.1111/j.1469-8137.2008.02528.x

BenNetT M. D. \& Leitch I. J. 2011. — Nuclear DNA amounts in angiosperms - targets, trends and tomorrow. Annals of Botany 107: 467-590. https://doi.org/10.1093/aob/mcq258

Biradar D. \& RAYBURN A. 1993. - Intraplant nuclear DNA content variation in diploid nuclei of maize (Zea Mays L.). Journal of Experimental Botany 44 (263): 1039-1044. https:// doi.org/10.1093/jxb/44.6.1039

Bothwell J. H., Marie D., Peters A. F., Cock J. M. \& Coelho S. M. 2010. - Role of endoreduplication and apomeiosis during parthenogenetic reproduction in the model brown alga Ectocarpus. New Phytologist 188: 111-121. https://doi.org/10.1111/j.14698137.2010.03357.x

Browdy C. L, Hulata G., Liu Z., Allan G. L., Sommerville C., Passos De Andrade T., Pereira R., Yarish C., Shpigel M., Chopin T., Robinson S., Avnimelech Y. \& Lovatelli A. 2012. - Novel and emerging technologies: can they contribute to improving aquaculture sustainability?, in SUBASINGHE R. P., Arthur J. R., Bartley D. M., De Silva S. S., Halwart M., Hishamunda N., Mohan C. V. \& Sorgeloos P. (eds), Farming the Waters for People and Food. Proceedings of the Global Conference on Aquaculture 2010. FAO, Rome and NACA, Bangkok, 149-191.

CHOI H. G., LeE Y. K. \& LeE I. K. 1994. - Measurement of DAPI stained DNA in Dasysiphonia chejuensis Lee et West (Rhodophyta) by a video interfaced digital image processor. Korean Journal of Phycology 9: 21-28.

Chung I. K., Ledbetter M. C. \& Brinkhuis B. H. 1987. — Final struture of Laminaria saccahrina (L.) Lamour. Algae 2 (2): 147-171.

Clowes A. W., Reidy M. A. \& Clowes M. M. 1983. - Kinetics of cellular proliferation after arterial injury. I. Smooth muscle growth in absence of endothelium. Laboratory Investigations 49: 327-333.

Cock J. M., Sterck L., Rouzé P., Scornet D., Allen A. E., Amoutzias G., Anthouard V., Artiguenave F., Aury J. M. \& BAdger J. H. 2010. - The Ectocarpus genome and the inde- pendent evolution of multicellularity in brown algae. Nature 465: 617-621. https://doi.org/10.1038/nature09016

Coleman A. W., Maguire M. J. \& Coleman J. R. 1981. — Mithramycin- and 4, 6-diamidino-2-phenylindole (DAPI)-staining for fluorescence microspectrophotometric measurement of DNA in nuclei, plastids, and virus particles. Journal of Histochemistry and Cytochemistry 29: 959-968. https://doi.org/10.1177/29.8.6168681

Collantes G., Merino A. \& Lagos V. 2002. - Fenología de la gametogénesis, madurez de conceptáculos, fertilidad y embriogénesis en Durvillaea antarctica (Chamisso) Hariot (Phaeophyta, Durvillaeales). Revista de Biologia Marina y Oceanografia 37 (1): 83-112. https://doi.org/10.4067/S0718-19572002000100009

Coyer J. A., Hoarau G., Pearson G. A., Serrão E. A., Stam W. T. \& Olsen J. L. 2006. - Convergent adaptation to a marginal habitat by homoploid hybrids and polyploid ecads in the seaweed genus Fucus. Biology Letters 2 (3): 405-408. https://doi.org/10.1098/rsbl.2006.0489

Davies J. M., Ferrier N. C. \&. Johnston C. S. 1973. - The ultrastructure of the meristoderm cells of the hapteron of Laminaria. Journal of the Marine Biological Association of the United Kingdom 53 (2): 237-246. https://doi.org/10.1017/S0025315400022232

Demes K. W., Graham M. H. \& SuskieWicz T. S. 2009. — Phenotypic plasticity reconciles incongruous molecular and morphological taxonomies: The giant kelp, Macrocystis (Laminariales, Phaeophyceae), is a monospecific genus." Journal of Phycology 45 (6): 1266-1269. https://doi.org/10.1111/j.1529-8817.2009.00752.x

Garbary D. J. \& Clarke B. 2002. - Intraplant variation in nuclear DNA content in Laminaria saccharina and Alaria esculenta (Phaeophyceae). Botanica Marina 45: 211-216. https://doi.org/10.1515/BOT.2002.020

Goff L. J. \& Coleman A. W. 1984. - Elucidation of fertilization and development in a red alga by quantitative DNA microspectrofluorometry. Developmental Biology 102: 173-194. https://doi.org/10.1016/0012-1606(84)90183-0

Goff L. J. \& Coleman A. W. 1990. — DNA: Microspectrofluorometric studies, in COLE K. M. \& SHEATH R. G. (eds), Biology of the Red Algae, Cambridge University Press, New York, 43-72.

Gómez Garreta A., Ribera Siguan M. A., Salvador Soler N., Rull Lluch J. \& Kapraun D. F. 2010. - Fucales (Phaeophyceae) from Spain characterized by large scale discontinuous nuclear DNA contents consistent with ancestral cryptopolyploidy. Phycologia 49: 64-72.

Gregory T. R., Nicol J. A., Tamm H., Kullman B., Kullman K., Leitch I. J., Murray B. G., Kapraun D. F., Greilhuber J. \& BenNeTT M. D. 2007. - Eukaryotic genome size databases. Nucleic Acids Research 35: D332-D338. https://doi.org/10.1093/ nar/gkm828

Greilhuber J, Doležel J., Lysak M. A. \& Bennett M. D. 2005. The origin, evolution and proposed stabilization of the terms 'Genome Size' and 'C-Value' to describe nuclear DNA contents. Annals of Botany 95: 255-260. https://doi.org/10.1093/aob/mci019

Hodgson J. G., Sharafi M., Jalili A., Diaz S., Montserrat-Marti G., Palmer C., Cerabolin B., Pierce S., Hamzehee B., Asri Y., Jamzad Z., Wilson P., Raven J. A., Band S. R., Basconcelo S., Bogard A., Carter G., Charles M., Castro-Diez P., Cornelissen J. H., Funes G., Jones G., Khoshnevis M., Perez-Harguindeguy N., Perez-Rontome M. C., Shirvany F. A., Vendramini F., YaZdani S., Rabbas-Azimi R., Boustani S., Dehghan M., Guerrero-Campo J., Hynd A., Kowsary E., Kazemi-Saeed F., Siavash B., Villar-Salvador P., Craigie R., Naqinezhad A., Romo-DieZ A., DE Torres Espuny L. \& SimMONS E. 2010. - Stomatal vs. genome size in angiosperms: the somatic tail wagging the genomic dog? Annals of Botany 105: 573-584. https://doi.org/10.1093/aob/mcq011

Hoffmann A. \& SANTEliCES B. 1997. - Flora marina de Chile Central, Ediciones Universidad Católica de Chile, Santiago, 434 p. KAPRAUN D. F. 2005. - Nuclear DNA content estimates in multicellular eukaryotic green, red and brown algae: phylogenetic 
considerations. Annals of Botany 95: 7-44. https://doi.org/10.1093/ $\mathrm{aob} / \mathrm{mci002}$

Kapraun D. F. \& NGUyen M. N. 1994. - Karyology, nuclear DNA quantification and nucleus cytoplasmic domain variations in some multinucleate green algae. Phycologia 33: 42-52. https://doi.org/10.2216/i0031-8884-33-1-42.1

Kapraun D. F. \& Dunwoody J. T. 2002. - Relationship of nuclear genome size to some reproductive cell parameters in the Florideophycidae (Rhodophyta). Phycologia 41: 507-516. https://doi.org/10.2216/i0031-8884-41-5-507.1

Katagiri Y., Hasegawa J., FujikURa U., Hoshino R., Matsunaga S. \& TSUKaYA H. 2016. - The Coordination of Ploidy and Cell Size Differs between Cell Layers in Leaves. Development. 143 (7): 1120-1125. https://doi.org/10.1242/dev.130021

KATSAROS C. \& GALATIS B. 1986. - Ultrastructural Studies on zoosporogenesis of Halopteris filicina (Sphacelariales, Phaeophyta). Phycologia 25 (3): 358-370. https://doi.org/10.2216/ i0031-8884-25-3-358.1

Kubešová M., Moravcová L., Suda J., JarošíK V. \& PYšEK P. 2010. - Naturalized plants have smaller genomes than their non-invading relatives: a flow cytometric analysis of the Czech alien flora. Preslia 82: 81-96.

Lavergne S., Muenke N. J. \& Molofsky J. 2010. — Genome size reduction can trigger rapid phenotypic evolution in invasive plants. Annals of Botany 105: 109-116. https://doi.org/10.1093/ aob/mcp271

Le Gall Y., Brown S., Marie D., MejJad M. \& Kloareg B. 1993. Quantification of nuclear DNA and G-C content in marine macroalgae by flow cytometry of isolated nuclei. Protoplasma 173: 123-132. https://doi.org/10.1007/BF01379001

LeitCH I. J. \& LeITCH A. R. 2013. - Genome size diversity and evolution in land plants, in LeItCH I.J., Greilhuber J., Dolezel J. \& Wendel J.F. (eds). Plant Genome Diversity, vol 2, Physical Structure, Behaviour and Evolution of Plant Genomes, Springer-Verlag, Wien, 307-322. https://doi.org/10.1007/9783-7091-1160-4_19

LEWIS R. J. 1996. - Chromosomes of the Brown Algae. (Phycological Reviews 16). Phycologia 35 (1): 19-40. https://doi.org/10.2216/ i0031-8884-35-1-19.1

LOISEAUX L. 1973. - Ultrastructure of zoidogenesis in unilocular zoidocysts of several brown algae. Journal of Phycology 9: 277283. https://doi.org/10.1111/j.1529-8817.1973.tb04094.x

Macchiavello J., Araya E. \& Bulboa C. 2010. — Production of Macrocystis pyrifera (Laminariales; Phaeophyceae) in northern Chile on spore-based culture. Journal of Applied Phycology 22: 691-697. https://doi.org/10.1007/s10811-010-9508-8

Magne F. 1952. - Méiose et nombre chromosomique chez les Laminariaceae (Laminariales, Phaeophyceae). Compte Rendu Hebdomadaire des Séances de l'Académie des Sciences. Paris. 236: 515-517.

MARMUR J. \& DOTY P. 1962. - Determination of the base composition of desoxyribonucleic acid from its thermal denaturation temperature. Journal of Molecular Biology 5: 109-118. https://doi.org/10.1016/S0022-2836(62)80066-7

Martin Martin R. P., Rull Lluch J. \& Gomez GarReta A. 2016. Identificación y cuantificación de $\mathrm{ADN}$ nuclear de algas antárticas. Algas 51 (junio 2016) Boletín Informativo de la Sociedad Española de Ficología 51: 81-84. https://doi.org/10.13140/2.1.2585.7280 MoTOMURA T. 1993. - Ultrastructural and inmunofluorescence studies of zoosporogenesis in Laminaria angustata. Scientific papers of the Institute of algological research, Faculty of Science, Hokkaido University 9 (1): 1-32.

Müller D. G., Maier I., Marie D. \& Westermeier R. 2016. Nuclear DNA level and life cycle of kelps: Evidence for sex-specific polyteny in Macrocystis (Laminariales, Phaeophyceae). Journal of Phycology 52 (2):157-160. https://doi.org/10.1111/jpy.12380 Oppliger L. V., Von Dassow P., Bouchemousse S., Robuchon M., Valero M., Correa J. A., Mauger S. \& Destombe C. 2014. - Alteration of sexual reproduction and genetic diversity in the Kelp Species Laminaria digitata at the Southern limit of its range. PLoS ONE 9 (7). https://doi.org/10.1371/journal. pone. 0102518

Phillips N., Kapraun D. F., Gómez Garreta A., Ribera Siguan M. A., Rull Lluch J., SAlvador SOler N., LeWIS R. \& KaWAi H. 2011. - Estimates of nuclear DNA content in 98 species of brown algae (Phaeophyta). AoB PLANTS 11 (1): 1-8. https://doi.org/10.1093/aobpla/plr001

PortUGAL J. \& WARING. 1988. - Assignment of DNA binding sites for DAPI and bisbenzimide (Hoeschst 33258). Comparative foot printing study. Biochimica et Biophysica Acta 949: 158-168. https://doi.org/10.1016/0167-4781(88)90079-6

RoBinson G. \& COLE K. 1971. - Cytological investigations of some North American species of the genus Alaria Greville. Botanica Marina 14: 53-58. https://doi.org/10.1515/botm.1971.14.1.53

Ribera Siguan M. A., Gómez Garreta A., Salvador Soler N., Rull Lluch J. \& Kapraun D. F. 2011. - Nuclear content estimates suggest a synapomorphy between Dictyota and six other genera of the Dictyotales (Phaeophyceae). Cryptogamie, Algologie 32 (2): 205-219. https://doi.org/10.7872/crya.v32.iss2.2011.205

Salvador Soler N., Gómez Garreta A. \& Ribera Siguan M. A. 2009. - Somatic meiosis in the life history of Bonnemaisonia asparagoides and Bonnemaisonia clavata (Bonnemaisoniales, Rhodophyta) from the Iberian Peninsula. European Journal of Phycology 44: 381-393. https://doi.org/10.1080/09670260902780782

Salvador Soler N., Macaya E. C., Rull Lluch J. \& Gomez GARRETA A. 2016. - Nuclear DNA Content in Gelidium chilense (Gelidiales, Rhodophyta) from the Chilean Coast. Revista de Biologia Marina y Oceanografia 51 (1): 113-122. https://doi.org/10.4067/S0718-19572016000100011

Sjøtun K., HeEsch S., Rull Lluch J., Martín Martín R., Gómez Garreta A., Brysting A. K. \& Coyer J. A. 2017. - Unravelling the complexity of salt marsh Fucus cottonii forms (Phaeophyceae, Fucales). European Journal of Phycology 52 (3): 360-370. https://doi.org/10.1080/09670262.2017.1309688

VÁsquez J. A. 2008. — Production, Use and Fate of Chilean Brown Seaweeds: Re-Sources for a Sustainable Fishery. Journal of Applied Phycology 20 (5): 457-467. https://doi.org/10.1007/ s10811-007-9308-y

Vásquez J. A., Piaget N. \& Alonso Vega J. M. 2012. — The Lessonia nigrescens fishery in Northern Chile: 'how you harvest is more important than how much you harvest.' Journal of Applied Phycology 24 (3): 417-426. https://doi.org/10.1007/ s10811-012-9794-4

Varela-Álvarez E., Gómez Garreta A., Rull Lluch J., Salvador Soler N., Serrao E. A. \& Ribera Siguan M. A. 2012. - Mediterranean species of Caulerpa are polyploid with smaller genomes in the invasive ones. PLOS ONE 7: e47728. https://doi.org/10.1371/journal.pone.0047728 